\title{
Correction to: A framework for managing regulatory policy life-cycle challenges: an empirical design
}

\author{
Abdulrahman Alrabiah ${ }^{1}$ (1) $\cdot$ Steve Drew ${ }^{2}$
}

Published online: 6 July 2021

(c) Springer Nature Limited 2021

\section{Correction to: Journal of Banking Regulation https://doi.org/10.1057/s41261-021-00158-0}

The table in Appendix A that indicates the Group column has $\mathrm{A}, \mathrm{B}, \mathrm{C}, \mathrm{D}, \mathrm{E}$, and $\mathrm{F}$, but the production team missed to

\section{Appendix}

A. Interview consolidated questions.

\begin{tabular}{lcl}
\hline Policy phase & Group & Related questions \\
\hline 1 & A. & 1. How you create a policy? \\
Engineering/Creation & & $\begin{array}{c}\text { 2. Please specify the coordination } \\
\text { and activities between SAMA's } \\
\text { departments to handle policy } \\
\text { creation }\end{array}$ \\
& 3. Please list the challenges or issues \\
& that you face during the creation \\
& stage of the regulatory policy \\
& 1. How you analyse the intended \\
& policy? \\
Analysis & 2. How you overcome issues \\
& appeared during the analysis stage? \\
& 3. Please list the challenges you \\
& encounter during policy analysis
\end{tabular}

The original article can be found online at https://doi.org/10.1057/ s41261-021-00158-0.

Abdulrahman Alrabiah

Abdul.alrabiah@griffithuni.edu.au; rabiah2@gmail.com

Steve Drew

steve.drew@utas.edu.au

1 School of ICT, Griffith University Gold Coast, Gold Coast Campus, 58 Parklands Dr, Southport, Gold Coast, QLD 4215, Australia

2 Academic Division, Tasmanian Institute of Learning and Teaching, University of Tasmania, Private Bag 133, Hobart, TAS 7001, Australia update this column in the original publication of the article. The correct table in Appendix A should read as given below:

\begin{tabular}{|c|c|c|}
\hline Policy phase & Group & Related questions \\
\hline \multirow{3}{*}{$\begin{array}{l}3 \\
\text { Validation }\end{array}$} & \multirow[t]{3}{*}{$\mathrm{C}$. } & 1. How you validate the policy? \\
\hline & & $\begin{array}{l}\text { 2. How you overcome issues } \\
\text { appeared during the validation } \\
\text { stage? }\end{array}$ \\
\hline & & $\begin{array}{l}\text { 3. Please list the challenges you } \\
\text { encounter during policy validation }\end{array}$ \\
\hline \multirow{4}{*}{$\begin{array}{l}4 \\
\text { Deployment/Execution }\end{array}$} & \multirow[t]{4}{*}{ D. } & 1. How do you deploy your policy? \\
\hline & & $\begin{array}{l}\text { 2. Why it takes a long time to imple- } \\
\text { ment the regulatory policy? }\end{array}$ \\
\hline & & $\begin{array}{l}\text { 3. What makes the currently imple- } \\
\text { mented regulatory policy system } \\
\text { inefficient, among other execution } \\
\text { shortcomings? }\end{array}$ \\
\hline & & $\begin{array}{l}\text { 4. Please list the challenges or } \\
\text { issues that you are facing during } \\
\text { the implementation of regulatory } \\
\text { policy }\end{array}$ \\
\hline \multirow[t]{5}{*}{$\begin{array}{l}5 \\
\text { Monitoring }\end{array}$} & \multirow[t]{5}{*}{ E. } & $\begin{array}{l}\text { 1. How do you monitor the imple- } \\
\text { mented policies? }\end{array}$ \\
\hline & & $\begin{array}{l}\text { 2. How do you report if you have } \\
\text { violations, weakness, or shortcom- } \\
\text { ings issues in the implemented } \\
\text { policies? }\end{array}$ \\
\hline & & $\begin{array}{l}\text { 3. Why many of the implemented } \\
\text { policies have negative feedback } \\
\text { loops and inefficient? }\end{array}$ \\
\hline & & $\begin{array}{l}\text { 4. Why do you not have an auto- } \\
\text { mated monitoring system for the } \\
\text { implemented policies? }\end{array}$ \\
\hline & & $\begin{array}{l}\text { 5. What are the challenges you cur- } \\
\text { rently encountering in this stage? }\end{array}$ \\
\hline
\end{tabular}


Policy phase

6

Optimisation
Group Related questions

F.

1. How do you measure the implemented policy?

2. How do you measure the return on policy (optimise)?

3. What is the set of procedures that employed to amend the existing policy to meet SAMA objectives?

4. Do you apply any optimisation model? If yes, please describe it. If No, why?

5. Please list the challenges that you face after the implementation of the policies
Publisher's Note Springer Nature remains neutral with regard to jurisdictional claims in published maps and institutional affiliations.

The original article has been corrected. 